\title{
THE TRANSFORMATION OF ADMINISTRATIVE LAW THROUGH LEGAL TRANSFERS: THE CASE OF GovernMENT AgenCies in Post-1989 Poland
}

\author{
PAULINA BIEŚ-SROKOSZ*
}

\section{INTRODUCTION}

As a result of the political changes that took place in Poland at the end of the 1980s a number of new (till this day) public administration bodies were established. The political transformation, which included a wide range of reforms, revolutions, changes, and modernisations, in a way forced the public administration to adjust to the new "reality" by performing public tasks which had not been stipulated by the law of the Polish People's Republic. What is more, none of the institutions (bodies) of that time had the organizational, financial, and human resources necessary to perform the new tasks. Thus, in order to fill in the institutional gaps and face new public challenges, the legislator frequently borrowed some of organizational and legal solutions by way of so-called transfers from other systems. Unfortunately, it was all done hastily and inconsistently, which will be accounted for in this paper.

It is stressed in the literature that the continual changes of social needs in modern states contribute to an increase of the number of tasks of a legal nature. As a consequence, public administration is faced with the problem of how to perform these tasks. The problem entails numerous political, organizational, praxeological, personnel, and legal-structural issues. The latter deserves a closer examination, for it concerns organizational forms of performing public tasks, and adjustment of those forms to new needs ${ }^{1}$. The subjective catalogue of organizational units performing public administration tasks is continually updated. It stems from the fact that, although new organizational units are formed, they do not fit within the traditional notion of public administration body ${ }^{2}$.

DOI: $10.1515 /$ wrlae-2018-0010

* PhD, Assistant Professor, Institute of Law, Administration and Management, Jan Długosz University, Częstochowa. Emai: p.bies@ ajd.czest.pl

${ }^{1} \mathrm{~J}$ Jagielski, M Wierzbowski, A Wiktorowska, Nietypowe podmioty administrujace-kilka refleksji na tle organizacyjnych form wykonywania zadań publicznych in: Podmioty administracji publicznej $i$ prawne formy ich działania. Studia $i$ materiaty z konferencji jubileuszowej Profesora Eugeniusza Ochendowskiego (Toruń 2005) 203.

${ }^{2}$ The administration body falls into the category of "public law bodies" which perform 
The application of legal transplants ${ }^{3}$, in other words borrowings from already functioning legal solutions as regards the organizational and legal sphere of the performance of public tasks, will be critically analysed in this paper.

The critical analysis of the transplantation of the German model of agency into Polish law will offer a chance to evaluate the validity and accuracy of that process. The analysis will be based on an examination of bills on selected government agencies and the $\mathrm{Sejm}^{4}$ stenographic records. However, it can already be said that, in their haste to transplant the German model of agency, the legislator produced confusing and inaccurate terminology such as e.g. supervision, which in fact is direction. The difference between direction and an institution exercising legal supervision is enormous, as it involves, inter alia, subordination to a superior authority, organizational and legal autonomy, or professional and personal subordination.

\section{THE RATIONALE FOR THE ESTABLISHMENT OF GOVERNMENT AGENCIES IN Poland}

As it has already been said, the political changes that took place at the end of the $20^{\text {th }}$ century contributed to the establishment of new organizational forms of public administration bodies. Their objective was to adapt administration, its operations and its organizational forms to perform new public tasks in the area of the economy. To be more specific, it included the tasks which involved e.g.: agricultural and military property management, financial aid for agricultural producers and agri-food producers and the storage of national reserves. The bodies operating within those new organizational forms were in conflict with the traditional notion

public tasks in the area of administration. In theory it is assumed that it is each body which has been statutorily delegated to perform public administration tasks. The notion of public law entity has been stipulated in Art. 2 par. 1 subpar. 4 of the Directive 2014/24/EU of the European Parliament and of the Council of 26 February 2014 on public procurement and repealing Directive 2004/18/EC (OJ L 94/65 28.3.2014) and Art. 3 Par. 4 of Directive 2014/25/EU of the European Parliament and of the Council of 26 February 2014 on procurement by entities operating in the water, energy, transport and postal services sectors and repealing Directive 2004/17/EC (OJ L 94/243, 28.3.2014). Bodies governed by public law' means bodies that have all of the following characteristics:(a) they are established for the specific purpose of meeting needs in the general interest, not having an industrial or commercial character; (b) they have legal personality; and (c) they are financed, for the most part, by the State, regional or local authorities, or by other bodies governed by public law; or are subject to management supervision by those authorities or bodies; or which have an administrative, managerial or supervisory board, more than half of whose members are appointed by the State, regional or local authorities, or by other bodies governed by public law.

${ }^{3}$ This term can be understood as as "rule shift or the legal system from one country to another. A Watson, Legal Transplants. An Approach to Comparative Law (Athens 1993) 21. In contrast, in the version presented by economic analysts, transplant law is perceived as a unilateral act of changing the legal order through which the power of one country imports legal standards from the other country. J Miller, 'A Typology of Legal Transplants: Using Sociology, Legal History and Argentine Examples to Explain the Transplant Process' (2003) 51 The American Journal of Comparative Law 845-868.

${ }^{4}$ The lower house of the Polish parliament. 
of a public administration body, that is a body established by way of an act and designed to perform public tasks, such as in the cases of local government units, libraries, public universities, hospitals etc. According to the literature, untypical bodies of public administration include, inter alia: public foundations, funds, the National Bank of Poland, the Polish Post, and government agencies ${ }^{5}$. Untypical bodies of public administration are still considered "a novelty" though they have been present in the public administration system for over 20 years. It stems from the fact that their formation and functioning within public administration have not been precisely defined and substantiated. Some of the scholars continually raise that issue in their papers and point to issues which deserve a more thorough attention in the literature ${ }^{6}$. Unfortunately, a considerable number of theoreticians have frequently tended to follow predictable and repetitive patterns of analysis, shunning analyses focused on issues regarding the status or functioning of a given body.

The formation process of Polish government agencies traces back to the 1990's. A sort of tendency to form such bodies could again be observed after the year 2001. According to administrative law scholars, agencies, including government agencies, are characterised by an untypical (specific) legal nature, which distinguishes them from typical public administration entities. In opinion of the author of this article, government agencies served as a golden mean which was to avert the threats to the functioning of the Polish economic system, and to deal with the instability of that system. Furthermore, they were being formed with an intention of solving problems resulting from the lack of specialist organs of public administration in the areas of the State Treasury property management and modernisation and innovation in agriculture. The Supreme Court of Poland ${ }^{7}$ also took a position on that issue. The Court pointed to the importance of forming state juridical persons such as government agencies as the entities designed to shift responsibility in the area of civil law economic relations from public officers to professional managers acting as organs of state juridical persons. It seems that the underlying purpose of establishing government agencies did not and does not only stem from satisfying social needs by performing untypical tasks, but also from an intention to transplant the "agency model" from other public systems. The legislator's actions could (and can) be motivated by the fact that it was not (is not) possible to create a totally new model of body which would perfectly fit into the Polish legal system. It stems from the fact that the legislator frequently searches for ready-made legal solutions which have successfully been implemented in other countries.

The thesis advanced above can be supported by the content of the

\footnotetext{
5 Also known as: administrative agencies, state agencies, government economic agencies. More in P Bieś-Srokosz, 'Public administration entities vs. specific (untypical) entities in the Polish administrative law system' (2014) 14/1 International and Comparative Law Review 77-86; P Bieś-Srokosz, Tworzenie agencji rządowych-odpowiedź ustawodawcy na potrzeby społeczeństwa in M. Giełda, R. Raszewska-Skałecka (eds), Administracja publiczna wobec wyzwań i oczekiwań społecznych (Wrocław 2015).

${ }^{6}$ Jagielski, Wierzbowski, Wiktorowska (n 1) 203 ff.

${ }^{7}$ Resolution of the Supreme Court of Poland of 27 April 2001, III CZP 12/01, OSNC 2001, No. 10, item 150.
} 
Sejm stenographic records which reveal the intentions of some groups lobbying for particular bills. For instance, in the bill on public finances from 2009 the legislator stated that government agencies had been established in order to perform key public tasks. Unfortunately, the expression "key public tasks" was not developed. Furthermore, the legislator wanted Polish government agencies to resemble executive agencies of the $\mathrm{EU}^{8}$. It seems, however, not to be a good idea, for government agencies are not and will never be the same as or similar to EU agencies, neither with regard to their performed tasks nor their status, operations and responsibilities ${ }^{9}$. Both the Polish government agencies and the EU agencies have a legal personality, but it is the only thing they actually have in common.

Nevertheless, the Polish legislator is using the term "executive agency" 10 more and more frequently, which also deserves a negative evaluation for, as a consequence, another administrative law term is introduced without either being explained or being distinguished from the term "government agency".

It should be now stressed that the EU law exerts an enormous influence on the way public administration bodies (institutions) function. Although the Polish legislator wanted to transplant some legal solutions

\footnotetext{
${ }^{8}$ The EU agencies are the bodies created by regulation, they have certain formal legal character, all have legal personality, multilevel organizational structure and all have a certain degree of autonomy. Communication from the Commission, The operating framework for the European Regulatory Agencies, COM 2002 (No. 718) 3; M Chamon, 'EU agencies: does the "Meroni" doctrine make sense?' (2010) 17/3 Maastricht Journal of European and Comparative Law $282 \mathrm{ff}$. However, it must be emphasized that in its draft of an inter-institutional agreement regarding the general framework for European regulatory agencies, the Commission did not develop that definition. Instead, the Commission defined regulatory agencies as legally autonomous bodies established by the legislator in order to facilitate the regulation of particular sectors at the European level and the implementation of the policy of European Communities. It can, therefore, be said that the Commission has not explained why so-called executive agencies should not fall under this definition, which enhances the feelings of obscurity and imprecision regarding the general definition of agency. Cf Draft Interinstitutional Agreement on the operating framework for the European regulatory agencies, COM 2005 (No 59) 6. The implemented division of European agencies into executive and regulatory ones stems from the tasks they perform. The executive agencies perform the tasks which contribute to the implementation of the programme of the EU. Furthermore, those bodies cannot have discretionary legal powers when it comes to the way political decisions are executed. Cf R Grzeszczak, Władza wykonawcza $w$ systemie Unii Europejskiej (Warszawa 2011) 212 ff. The regulatory agencies perform basic tasks, but only few of them are authorized to make decisions. Cf $\mathbf{J}$ Supernat, Administracja Unii Europejskiej. Zagadnienia wybrane (Wrocław 2013) 105106. Commenting on the definitions proposed by scholars, one should get acquainted with the definition of executive agency of the EU by S Griller and A Orator. According to the scholars, the agency is a relatively autonomous, permanently existing entity that has a legal personality, is separated from the secondary legislation of the EU and "burdened" with special tasks. Cf S Griller, A Orator, 'Everything under control? The way forward for European agencies in the footsteps of the Meroni Doctrine' (2010) 35 European Law Review 7.

9 Agencies are autonomous and separate from the main bodies of the public authorities, which means that they are not part of the institutional system of any EU body. European Union agencies are mainly created in the area of broadly understood security. Unlike in Poland, because Polish agencies are created to perform economic tasks.

10 The term "executive agency" is broader than the term ,government agency", for it encompasses the agency in the wide sense (offices, sole-shareholder companies of the State Treasury) and in the narrow sense (government agencies).
} 
from the EU agencies to Polish government agencies ${ }^{11}$, the legal form in which the latter function now seems valid and sufficient. It stems from the fact that European agencies have a slightly different legal nature as well as different responsibilities and tasks. Therefore, it is not possible to compare Polish government agencies to the EU ones and, consequently, to change the way the former function according to the way the latter do.

In order to acquire EU funds, member states have to undertake actions of two types: central and regional ${ }^{12}$. The central actions involve both the legislator and the central administration who have to implement proper systemic and legal solutions, and proper mechanisms at national and regional levels. When it comes to the regional actions, regions are obliged to build new administrative apparatus and to establish cooperation between local government units.

The adoption of the EU legal order and requirements as regards the functioning of institutions (bodies) performing tasks in the area of economy entailed the establishment of the following Polish government agencies: the Agency for Restructuring and Modernisation of Agriculture, the Agricultural Market Agency, and the Polish Agency for Enterprise Development.

The predominant view present in the literature, however, is that the main rationale for establishing government agencies in Poland was the performance of public tasks of economic character by specialized bodies (e.g. government agencies). Most of the scholars point out that government agencies have been established in order to relieve public administration bodies of some of their work, and in order to keep up with the new needs of the state and of society ${ }^{13}$.

\section{The Polish or the German model of government agency?}

Sometimes it is difficult to discern if there was (is) a certain idea behind a legislator's actions, for one may often have an impression that those actions are copies of solutions already existing in other legal systems. Such is the case with Polish government agencies which resemble the German ones. The Basic Law for the Federal Republic of Germany ${ }^{14}$ (the constitutional law) introduced two types of agencies: direct (unmittelbare

\footnotetext{
${ }^{11}$ The grounds for such reasoning can be found in the reasons for the Act of 2009 on public finances

12 A Wojczyńska, 'Zasady i system zarządzania środkami strukturalnymi przeznaczonymi na rozwój regionalny’ (2007) 1 Edukacja Prawnicza 8.

${ }^{13}$ More in Bieś-Srokosz, Tworzenie (n 5) 23-26.

14 The Constitution of the Federal Republic of Germany of 29 July 2009 (BGBl. I S. 2248), mainly the article 86. The federal agencies in Germany are established to assist the country's executive branch on the federal level according to which they are hierarchically organized on four levels: 1. low-level federal agencies are subordinate to middle-level agencies and are responsible for relatively small areas such as District Recruiting Offices, Waterways and Shipping Offices or Chief Customs Offices; 2. middle-level federal agencies are situated between a federal ministry and the lowest administrative level. Their responsibilities are limited to specific regions; 3. upper-level federal agencies can be established. These agencies are directly attached subordinate to a federal ministry and mostly do not have any agencies subordinate to them and 4. top-level federal agencies which are distinguished from all other levels as they are specifically for e.g.: the administrative office of the Bundesrat, the Press and Information Agency of the Federal Government.
} 
Bundesverwaltung) and indirect (mittelbare Bundesverwaltung). The former are a part of the state and are not legally independent. The latter have a legal personality based on public law. The major difference between them is that indirect agencies have autonomy guaranteed by law, which can be demonstrated with their budget. The budget of an indirect agency is prepared by the agency itself and then approved by a competent minister whereas the budget of a direct agency is a part of the budgetary plans of a ministry which a given agency is subordinate to. As a consequence, direct agencies cannot freely implement regulations on finance management in the public sector.

Direct and indirect agencies differ in terms of their management structure. Indirect agencies have ordinary management boards consisting of lobbyists, MPs, representatives of ministries, or all of them together. For instance, the board of Federal Employment Agency involves unions, employers, and representatives of the government. The boards decide about the draft budgets of indirect agencies and exercise supervision over their management. By contrast, direct agencies do not have distinct managing groups (they may have advisory bodies which, however, have no formal authorisation to make decisions). What is more, having considered that direct agencies are managed by chairmen, boards are more common in indirect agencies ${ }^{15}$.

Another clear difference between direct and indirect agencies emerges when one looks more closely at what they deal with in the area of social policy. As a rule only direct agencies perform basic functions of the public sector, which mainly involves passing regulations on drugs, general competition, immigration, statistics, industrial property law, and the protection of public order ${ }^{16}$. Those functions are usually devolved, by way of an act, to higher or intermediate federal authorities (which resemble decentralised organizations). When it comes to federal institutions, they are established by way of a ministerial decree in order to: do research, provide consulting services, perform health promotion, do research on agriculture and IT.

Most of indirect agencies have the status of state organs which are normally responsible for social security systems (unemployment, accidents, illnesses, long-term care). Most of those organs are not directly supervised by ministries, and they do not have representatives of the government on their boards. It means that ministers are not authorised to supervise and administer those organs. As a rule agencies are financed from the state budget, though there are some exceptions.

In order to be able to implement the state policy, federal agencies have been given quite a lot of autonomy, which particularly concerns issues connected with their main activity and setting priorities. Indirect agencies are much more autonomous as regards their general activity and setting their priorities ${ }^{17}$. It must be noted that an agency's involvement in shaping its policy manifests itself in the fact that agencies often serve as sources of

\footnotetext{
${ }^{15} \mathrm{~T}$ Bach, W Jann, 'Structure and governance of agencies in Germany: A lot of continuity and little change' in PG Roness, H Saetren (eds), Change and continuity in public sector organizations (Bergen 2009) $127 \mathrm{ff}$.

16 ibid.

17 ibid 127-147.
} 
information for ministries they are subordinate to ${ }^{18}$. It is a task performed by numerous agencies. The results of a survey conducted by Comparative Public Organization Data Base for Research and Analysis ${ }^{19}$ indicate various levels of the agencies' politicization and a variety of actions undertaken as a part of their development ${ }^{20}$. It should be noted that the agencies' involvement in working on financial policy depends, to a large extent, on the will of government administration which determines the level of the contribution of a given agency to the state policy. In addition, the experience of agencies is utilized when preparing political solutions regarding their organization and finances.

When it comes to the issue of supervision, it must be stated that, as a rule, direct agencies are subject to two types: hierarchical-functional and legal. Functional supervision concerns employees, organizational structure, and the use of formal procedures. Legal supervision (Rechtsaufsicht) is more limited, for it enables a competent minister to review the regulations applied by an agency as regards their compliance with superior legal acts. As far as indirect agencies are concerned, competent ministers exercise only legal supervision. Only a few ministries have principles governing the exercise of functional supervision distinctly stipulated.

In 2008 the ministers consented to pass inter-departmental guidelines on the exercise of functional supervision ${ }^{21}$. According to the departmental principle of independence, each ministry can independently decide whether to or how to implement those guidelines (which are general and contain mainly a list of the aims of that supervision and the tools necessary to exercise it).

According to the research conducted by the COBRA company, the ministerial supervision exercised over indirect agencies was more diverse than the supervision exercised over direct agencies ${ }^{22}$. The supervision exercised by ministers concerned mainly management issues rather than the policy, which manifests itself in a high level of the agencies' autonomy, the possibility to make hierarchical interventions in political decisions, and numerous restrictions as regards making decisions about finances and personnel issues ${ }^{23}$. It stems from "a strong conviction that giving authorities a mandate is sufficient to ensure administrative efficiency" 24 . That mandate is rooted in the administrative tradition of the country (Rechtsstaat).

Unlike in other countries, new quasi-autonomous entities are not being created in Germany, and the number of agencies is decreasing. That process is characterised by transforming and merging agencies into more autonomous legal bodies. Although some agencies had clearly worded

\footnotetext{
${ }^{18}$ More in M Döhler, Die politische Steuerung der Verwaltung, "Staatslehre und politische Verwaltung" (Baden-Baden 2007).

${ }^{19}$ COBRA.

${ }^{20} \mathrm{~T}$ Bach, 'Policy and management autonomy of federal agencies in Germany' in $\mathrm{P}$ Leagreid, K Verhoest (eds), Governance of Public Sector Organizations-Proliferation, Autonomy and Performance (Hampshire 2010) 89-110.

21 ibid.

${ }^{22} \mathrm{I}$ am referring to the data provided by $\mathrm{T}$ Bach.

${ }^{23}$ Bach (n 20) $91 \mathrm{ff}$.

${ }^{24} \mathrm{~T}$ Bach, W Jann, 'Animals in the administrative zoo: organizational change and agency autonomy in Germany’ (2010) 3 International Review of Administrative Sciences 462.
} 
contracts with a competent minister, it seems that quality management tools are more frequently used for the purposes of the agencies' internal management rather than efficiency-based ministerial supervision.

Without a doubt, the Polish legislator has adopted the German model of government agency. There are a number of similarities. Firstly, is the legal basis for establishing such bodies (by means of statutory provision); secondly, agencies are directly managed by chairmen; thirdly, the objective scope of the operations performed by the agencies is convergent in areas such as the army, property management, and support of agricultural production; fourthly, the activity of both Polish and German agencies is financed from the state budget; finally, in both models there is a hierarchical bond between a minister and a given agency.

Can one therefore say whether there is a German or a Polish model of agency? It is not possible to provide an unequivocal answer to that question. Nevertheless, a reasonable conclusion can be drawn that the Polish legislator has transplanted numerous elements and features of German agencies into the Polish system of law. Moreover, the remaining elements of Polish agencies are patterned after the German ones. It should be stressed, however, that those operations were performed inaccurately, which resulted in a number of terminological and substantive errors. It can be illustrated with an example of the supervision exercised by a competent minister over the actions performed by government agencies. Having analysed the provisions on the functioning of government agencies, it must be stated that the legal supervision over the agencies takes the form of direction. Even though the view that it is "purely" legal supervision prevails in the theory of administrative law, the competence of ministers along with professional and personal subordination of the chairmen of agencies indicates that we can say it is direction rather than supervision. A considerable number of administrative law experts claim that the notion of supervision in centralised administration should be considered against broadly defined notions such as direction, authority, and subordination ${ }^{25}$. As a consequence, the notion of supervision is valid only when there is no organizational connection between units. If there is, however, the notion should be abandoned in favour of the notion of direction ${ }^{26}$. Further examination of that matter goes beyond the scope of this paper. Yet, it is worthy of a closer look and thus will be discussed in a separate article.

\section{Polish government agencies or executive agencies of the EU?}

The idea that the already existing and new government agencies should be patterned after executive agencies of the EU seems pointless and misguided, which has been pointed out earlier in the paper. Those bodies differ when it comes to their organizational structures, objective scope of the performed tasks, competences, and impact on economic policy. The

${ }^{25}$ Cf W Dawidowicz, Wstęp do nauk prawnoadministracyjnych (Warszawa 1974) $103 \mathrm{ff.} \mathrm{Z}$ Rybicki, System rad narodowych w PRL (Warszawa 1971) 407-408; Z Szydłowski, Nadzór w systemie rad narodowych w uktadzie pionowym (Bydgoszcz 1970) 37-39; M Miemiec, 'Prewencja

i weryfikacja w ramach nadzoru i kierownictwa w ujęciu tradycyjnym' in C Kociński (ed), Nadzór administracyjny. Od prewencji do weryfikacji (Wrocław 2006) 40.

${ }^{26}$ Cf J Boć, T Kuta, Prawo administracyjne. Zagadnienia podstawowe (Warszawa 1984) 122. 
legislator's endeavours to treat the notions "government agency" and "executive agency" equally should be criticized, for in so doing, a new administrative law term is introduced before a proper definition of the previous one is provided. Another unfortunate decision was to use the term executive agency ${ }^{27}$ with reference to the Military Property Agency in the Act on the Military Property Agency ${ }^{28}$. Thus two questions arise; whether the remaining government agencies ${ }^{29}$ still have the status of government agencies or perhaps they are already executive agencies, and whether the Military Property Agency is exclusively an executive agency or a government agency called an "executive agency"?

It is impossible to provide unequivocal answers to the above questions. Nonetheless, it is possible to point out a lack of consistency in how the legislator uses the terms "government agency" and "executive agency". An analysis of the Sejm stenographic records from the work on the bill on the Military Property Agency ${ }^{30}$ reveals that the persons responsible for the preparation of the bill used those terms interchangeably without distinguishing between them, which obviously was improper. As has already been said, the problem stems from how the government agency and the executive agency are defined. In this case it is difficult to accept one, proper definition which would account for the essence and features of the Military Property Agency. In my view, it would be better if both the scholars and the legislator used the term "government agency".

Taking into account the content of the aforementioned stenographic records it must be stated that the Military Property Agency was established, firstly, because the European and global arms market had changed to such an extent that many countries did not want to negotiate the purchase of armaments with entrepreneurs-producers anymore and delegated that task to such agencies; secondly, it had been a common practice in other countries to establish government agencies which were authorised to buy and sell military property on behalf of ministries of defence and pursuant to intergovernmental agreements. According to General Wlodzimierz Nowak, the Head of the Armament Policy Department at the Ministry of National Defence, the rationale behind the adoption of such solution is that "The Military Property Agency could act as an executive agency of the Minister of National Defence. As stipulated by Article 57, pursuant to a Minister's decision issued under an agreement between governments, the Military Property Agency can act as a government agency performing tasks connected with the fulfilment of that agreement" 31 .

The above quotation from General Wlodzimierz Nowak is an example supporting my view that there is a lack of consistency in using the terms "government agency" and "executive agency". Furthermore, as can be seen from the aforementioned stenographic records, the establishment of the

\footnotetext{
${ }^{27}$ Act of 10 July 2015 on Military Property Agency (Journal of Laws of 2015, item 1322).

${ }^{28}$ Art. 5 par. 1 of the Act.

${ }^{29}$ Agency for Restructuring and Modernisation of Agriculture, Agricultural Market Agency, Material Reserves Agency, Polish Agency for Enterprise Development, Agricultural Property Agency.

${ }^{30}$ http://orka.sejm.gov.pl/Zapisy7.nsf/wgskrnr/OBN-128, Bulletin No. 4731/VII.

31 ibid.
} 
Military Property Agency as a new, untypical body of public administration was motivated by the fact that similar entities already existed in other countries. Hence that solution was transplanted into the Polish law with hope that it would be successful here.

Having considered particular government agencies it must be stated that their organizational and legal forms follow the German model. However, the rationale behind their establishment lies, mainly, in the EU requirements. The Polish Agency for Enterprise Development, for instance, was established as a result of the transformation of the Polish Foundation for the Promotion and Development of Small and Medium-sized Enterprises. In the grounds for the bill on Polish Agency for Enterprise Development $^{32}$ it was emphasised that the bill was compliant with the solutions already existing in other member states of the EU and that the objective scope of the Agency was to be very similar to the one of the French Agency for Creating Enterprises, the Irish Agency FORBAIT, or the Swedish National Board for Industrial and Technical Development.

\section{CONCLUSIONS}

Before the final conclusions are formulated it must once again be stressed that the political transformation in Poland entailed further changes in the economic system and an increased number of social needs. The new authorities were faced with totally new public tasks which were designed to improve the quality of economic, social, and political life. Unfortunately, the then Polish legislator did not have the legal tools necessary to delegate public tasks to specialized institutions. It can be described as an institutional gap. At that time, the transplantation of ready legal solutions (models) from other countries seemed an ideal solution. Considering that issue through the prism of government agencies it must be said that the legislator borrowed not only the German organizational and legal model, but also copied the German terminology.

Such a policy adopted by the Polish legislator deserves criticism. The idea of creating government agencies itself should be supported, but they should be adjusted to the Polish legal system and social needs. However, the haste, the terminological inconsistency, and the willingness to transplant the solutions which have proved useful in other countries have a negative impact on how the legislator's actions are eventually perceived. In my opinion, the Polish legislator creating Polish agencies or transforming them should consider several factors. The first is what legal order is in place and what are the needs of society to adapt new agency regulations. Transplanting solutions from other legal systems can result in some confusion. As I mentioned earlier, in the German system there is supervision on the agencies, which is in the Polish system as well. However, after reviewing all the laws regulating the operation of government agencies, I found that it was not supervision but leadership. Personal and organizational subordination is to the competent minister or prime minister. In

\footnotetext{
32 http://orka.sejm.gov.pl/Rejestrd.nsf/wgdruku/1700/\$file/1700.pdf (Druk Sejmowy No. $1700) 16$.
} 
administrative law such a difference is of great importance because we can not talk about the autonomy of the subject or his autonomy in carrying out his tasks. In this case we are dealing with de-concentration and not with decentralization of entities.

The analysis of the bills and the stenographic records confirms that the legislator wants (wanted) to transplant ready-made legal solutions which could hopefully be useful and beneficial to the Polish legal system. Moreover, the legislator does not know how to fill in the institutional gap. The most popular arguments used by the legislator were "it proved successful in a different country" or "let's create agencies based on the EU model", quite obviously without a more thorough analysis as to how agencies functioned in other legal systems. Unfortunately, the consequences of the legislator's past actions can be experienced now ${ }^{33}$. Both the regulations and the terminology of administrative law contain the terms "government agency" and "executive agency", but since their meanings differ to a considerable extent, they should not be regarded as equal and should not be used interchangeably.

\section{Bibliography}

Books, articles and documents:

Bach T, Jann W, Structure and governance of agencies in Germany: A lot of continuity and little change in PG Roness, H Saetren (eds), Change and continuity in public sector organizations (Bergen 2009).

Bach T, Jann W, Animals in the administrative zoo: organizational change and agency

autonomy in Germany' (2010) 3 International Review of Administrative Sciences. Bach T, 'Policy and management autonomy of federal agencies in Germany' in $\mathrm{P}$ Leagreid, K Verhoest (eds), Governance of Public Sector Organizations-Proliferation, Autonomy and Performance (Hampshire 2010).

Bieś-Srokosz P, 'Public administration entities vs. specific (untypical) entities in Polish administrative law system' (2014) 14/1 International and Comparative Law Review.

Bieś-Srokosz P, 'Tworzenie agencji rządowych- odpowiedź ustawodawcy na potrzeby społeczeństwa' in M Giełda, R Raszewska-Skałecka (eds), Administracja publiczna wobec wyzwań i oczekiwań społecznych (Wrocław 2015).

Boć J, Kuta T, Prawo administracyjne. Zagadnienia podstawowe (Warszawa 1984).

Chamon M, 'EU agencies: does the "Meroni” doctrine make sense?' (2010) 17/3 Maastricht Journal of European and Comparative Law.

Communication from the Commission, The operating framework for the European Regulatory Agencies, COM 2002 (No. 718).

Dawidowicz W, Wstep do nauk prawnoadministracyjnych (Warszawa 1974).

Döhler M, Die politische Steuerung der Verwaltung, "Staatslehre und politische Verwaltung" (Baden-Baden 2007).

Draft Interinstitutional Agreement on the operating framework for the European regulatory agencies, COM 2005 (No 59).

Griller S, Orator A, 'Everything under control? The way forward for European agencies in the footsteps of the Meroni Doctrine' (2010) 35 European Law Review.

\footnotetext{
${ }^{33}$ The law on public finances refers to executive agencies, where, apart from government agencies, there are also mentioned other entities. On the other hand, in the laws of individual government agencies, the legislator defines them as government agencies and sometimes as executive agencies. There is a difference between the term "government agency" and "executive agency", since the former are narrower and are in the second.
} 

2011)

Grzeszczak R, Władza wykonawcza w systemie Unii Europejskiej (Warszawa

Jagielski J, Wierzbowski M, Wiktorowska A, 'Nietypowe podmioty administrujące-kilka refleksji na tle organizacyjnych form wykonywania zadań publicznych' in Podmioty administracji publicznej i prawne formy ich działania. Studia $i$ materiaty z konferencji jubileuszowej Profesora Eugeniusza Ochendowskiego (Torun 2005).

Miemiec M, 'Prewencja i weryfikacja w ramach nadzoru i kierownictwa w ujęciu tradycyjnym’ in C Kociński (ed), Nadzór administracyjny. Od prewencji do weryfikacji (Wrocław 2006).

Miller J, 'A Typology of Legal Transplants: Using Sociology, Legal History and Argentine Examples to Explain the Transplant Process' (2003) 51 American Journal of Comparative Law.

Rybicki Z, System rad narodowych w PRL (Warszawa 1971). 2013).

Supernat J, Administracja Unii Europejskiej. Zagadnienia wybrane (Wrocław (Bydgoszcz 1970).

Szydłowski Z, Nadzór $w$ systemie rad narodowych $w$ układzie pionowym

Watson A, Legal Transplants. An Approach to Comparative Law (Athens 1993).

Wojczyńska A, 'Zasady i system zarządzania środkami strukturalnymi przeznaczonymi na rozwój regionalny’ (2007) 1 Edukacja Prawnicza.

Legal acts:

Directive 2014/24/EU of the European Parliament and of the Council of 26 February 2014 on public procurement and repealing Directive 2004/18/EC (OJ L 94/65 28.3.2014).

Directive 2014/25/EU of the European Parliament and of the Council of 26 February 2014 on procurement by entities operating in the water, energy, transport and postal services sectors (OJ L 94/243 28.3.20140.

The Constitution of the Federal Republic of Germany of 29 July 2009 (BGBl. I S. 2248).

Act of 10 July 2015 on Military Property Agency (Journal of Laws of 2015, item

Website:

http://orka.sejm.gov.pl/Zapisy7.nsf/wgskrnr/OBN-128 (Bulletin No. 4731/VII). No. 1700).

http://orka.sejm.gov.pl/Rejestrd.nsf/wgdruku/1700/\$file/1700.pdf (Druk Sejmowy 